\title{
FAKTOR-FAKTOR YANG MEMPENGARUHI LOYALITAS KONSUMEN TOKO STARS MADIUN 2
}

\author{
Ridha Maisaroh ${ }^{1}$, Maulida Nurhidayati ${ }^{2}$ \\ ${ }^{1,2}$ Institut Agama Islam Negeri Ponorogo \\ Email: ridamaisyaroh@gmail.com ${ }^{1}, \underline{\text { nurhidayati@iainponorogo.ac.id }{ }^{2}}$
}

\begin{abstract}
Abstrac: Consumer loyalty is a positive attitude given by consumers to a product or company caused by consumer satisfaction with the product or company which is manifested by repeat purchase behavior to recommend it to anyone they know. This study aims to determine and analyze the effect of price, promotion, and service quality on consumer loyalty at Stars Madiun 2 Store. This research is a field research with a quantitative approach. Stars Madiun 2 shop consumers are the population in this study with 97 consumers as samples. Sampling was done by incidental sampling method. Data were analyzed by Partial Least Square (PLS) method. The results showed that price and promotion had a positive effect on consumer loyalty. While the quality of service has no effect on consumer loyalty. The magnitude of the influence of price, promotion, and service quality on consumer loyalty has an effect of $66.5 \%$ and $33.5 \%$ is influenced by variables that are not included in the model. The price variable has the greatest contribution to loyalty. The Stars Madiun 2 store must consider prices more carefully, such as providing more competitive prices, and offering a variety of products accompanied by good quality. After that, promotion and service quality can be improved.
\end{abstract}

Keywords: Price, Promotion, Quality of Service, Consumer Loyalty, Partial Least Square (PLS)

Abstrak: Loyalitas konsumen merupakan sikap positif yang diberikan oleh konsumen kepada suatu produk atau perusahaan yang disebabkan oleh kepuasan konsumen terhadap produk atau perusahaan tersebut yang diwujudkan dengan perilaku pembelian berulang hingga merekomendasikannya kepada siapapun yang mereka kenal. Penelitian ini memiliki tujuan untuk mengetahui dan menganalisis pengaruh harga, promosi, dan kualitas pelayanan terhadap loyalitas konsumen Toko Stars Madiun 2. Penelitian ini adalah penelitian lapangan dengan pendekatan kuantitatif. Konsumen Toko Stars Madiun 2 merupakan populasi pada penelitian ini dengan 97 konsumen sebagai sampel. Pengambilan sampel dilakukan dengan metode incidental sampling. Data dianalisis dengan metode Partial Least Square (PLS). Hasil penelitian menunjukkan bahwa harga dan promosi berpengaruh positif terhadap loyalitas konsumen. Sedangkan kualitas pelayanan tidak berpengaruh terhadap loyalitas konsumen. Besarnya pengaruh harga, promosi, dan kualitas pelayanan terhadap loyalitas konsumen berpengaruh sebesar $66,5 \%$ dengan 33,5\% dipengaruhi oleh variabel yang tidak masuk dalam model. Variabel harga memiliki kontribusi paling besar terhadap loyalitas. Toko Stars Madiun 2 harus lebih mempertimbangkan harga dengan matang, seperti memberikan harga yang lebih kompetitif, dan bermacam-macam dengan diiringi dengan kualitas produk yang baik. Setelah itu dapat dilakukan peningkatan promosi dan kualitas pelayanan.

Kata Kunci: Harga, Promosi, Kualitas Pelayanan, Loyalitas Konsumen, Partial Least Square (PLS) 


\section{PENDAHULUAN}

Di era sekarang ini, kondisi persaingan usaha sangatlah ketat, sehingga perusahaanpun dituntut untuk bersikap kompetitif. Hal ini dilakukan supaya usaha yang dijalankan dapat berkembang dan sukses seperti tujuan dari perusahaan. Jika setelah periode waktu tertentu suatu usaha mengalami peningkatan baik dalam hal modal, skala usaha, profit, jenis usaha maupun manajemen maka usaha tersebut dikatakan berhasil (Suarmawan, 2015).

Apapun jenis usahanya, salah satu kunci sukses dalam berbisnis adalah mempunyai hubungan yang baik dengan konsumen(Arnina P, 2016). Maka dari itu perusahaan harus bisa menciptakan ide ataupun gagasan yang dapat memunculkan nilai tersendiri bagi usahanya agar dapat menarik konsumen. Karena semakin banyak konsumen yang dapat ditarik oleh suatu perusahaan, maka semakin banyak kesempatan yang dimiliki perusahaan untuk membangun loyalitas konsumen.

Menurut Griffin yang dikutip oleh Ratih disebutkan bahwa "Loyalty is defined as non random purchase expressed over time by some decision making unit”. Berdasarkan pengertian tersebut, loyalitas lebih mengacu pada perilaku unit pengambil keputusan untuk terus menerus membeli barang atau jasa dari perusahaan terpilih (Hurriyati, 2015). Loyalitas merupakan komitmen berkelanjutan pelanggan untuk berlangganan kembali atau membeli kembali produk atau layanan tertentu secara konsisten di masa depan, terlepas dari dampak kontekstual dan upaya pemasaran yang dapat menyebabkan perubahan perilaku(Hurriyati, 2015). Menurut Shet dan Mittal, Loyalitas pelanggan merupakan komitmen pelanggan terhadap toko, merek, atau pemasok yang didasarkan pada sikap yang sangat positif yang diwujudkan dalam pembelian berulang secara konsisten(Huda, Novarini, Mardoni, \& Sari, 2015). Dari uraian dan pemaparan para ahli dapat diambil kesimpulan bahwa loyalitas konsumen sangatlah penting bagi perusahaan.

Menurut Swastha dan Handoko sebagaimana dikutip oleh Taufiqqurrahman dan Wijayanto, loyalitas konsumen dipengaruhi oleh kualitas produk, kualitas pelayanan, emosional, harga, dan biaya(Sukpa, Wijayanto, \& Taufiqurrahman, 2015). Menurut Dharmamesta, faktor yang mempengaruhi loyalitas konsumen antara lain kualitas produk, harga, dan promosi(Dharmmesta, 1999). Penelitian ini difokuskan pada harga, promosi, dan kualitas pelayanan sebagai faktor yang berpengaruh terhadap loyalitas konsumen. 
Menurut Dharmamesta, harga adalah salah satu faktor yang mempengaruhi loyalitas konsumen(Dharmmesta, 1999). Menurut Tjiptono, harga dapat didefinisikan sebagai sejumlah uang (satuan mata uang) dan/atau aspek lain (non-moneter) yang mencakup kegunaan/penggunaan tertentu yang diperlukan untuk memperoleh barang atau jasa(Fandi Tjiptono, 2014). Harga merupakan biaya yang dikenakan untuk produk atau jasa(Philips Kotler \& Armstrong, 2008).

Selain harga, faktor yang mempengaruhi loyalitas konsumen adalah promosi(Dharmmesta, 1999). Promosi merupakan mekanisme pemasaran yang berfokus pada komunikasi kegiatan pemasaran secara persuasif menargetkan pelanggan untuk memfasilitasi transaksi atau pengiriman antara perusahaan dan konsumen untuk membeli kegiatan yang diperlukan(Hasan, 2015). Menurut Rosalina, yang dikutip oleh Nabila dan Putu dalam penelitiannya menyatakan promosi menekankan pentingnya loyalitas konsumen, karena jika promosi meningkat maka perusahaan dapat lebih meningkatkan kualitas produk atau jasa, sehingga dapat meningkatkan keputusan pembelian dan loyalitas pelanggan(Insani \& Madiawati, 2020).

Selain harga dan promosi, faktor yang memberikan pengaruh pada loyalitas konsumen adalah kualitas pelayanan(Sukpa dkk., 2015). Kualitas pelayanan merupakan pernyataan sikap, hubungan antara harapan (expectations) dan kinerja (results). Definisi kualitas layanan adalah untuk mengukur sejauh mana layanan yang dapat diberikan untuk memenuhi harapan pelanggan(Lupiyoadi, 2008). Kualitas pelayanan dapat diartikan sebagai upaya untuk memuaskan kebutuhan dan keinginan konsumen, serta ketepatan dalam penyampaiannya yang seimbang sesuai dengan harapan konsumen(Atmaja, 2018). Menurut Sinurat, yang dikutip oleh Nabila dan Putu dalam penelitiannya, kualitas pelayanan berdampak pada pelanggan khususnya loyalitas pelanggan, jika perusahaan dapat menunjukkan kualitas pelayanan yang lebih baik, maka pelanggan akan puas dan loyal terhadap produk dan jasa perusahaan(Insani \& Madiawati, 2020). Thomas S. Khaihatu, Achmad Daengs dan Agus Tinus Lis Indrianto mengemukakan dalam bukunya Complaint Management, mengatakan bahwa kualitas pelayanan berpengaruh positif terhadap loyalitas konsumen. Dengan kata lain, semakin tinggi tingkat kualitas layanan, maka semakin tinggi pula loyalitas pelanggan(Khaihatu, Daengs, \& Indrianto, 2015).

Berdasarkan hasil wawancaran dengan Bapak Moh. Arifin selaku supervisor/ kepala toko pada tanggal 13 April 2021 diperoleh informasi bahwa Toko Sepatu Stars 
merupakan sebuah toko yang menjual produk sandal dan sepatu. Toko Stars saat ini memiliki kurang lebih 400 toko yang menyebar di seluruh wilayah Indonesia. Di wilayah Kabupaten dan Kota Madiun, terdapat 3 outlet, outlet yang pertama yaitu Toko Stars Madiun 2 yang beralamatkan di Jalan Panglima Sudirman No. 198 Kartoharjo Madiun. Toko Stars Madiun 2 ini khusus menjual barang barang new arrival atau barang barang baru. Produk yang dijual di outlet ini merupakan produk dari brand ardiles, starlady, kings star, RA Jeans, Nineten, Jane Vanda, Axxe, Ova, Lubrene, Umbrella, Sparta, Conae, dan lain-lain. Outlet yang kedua yaitu Toko Stars Madiun 3 yang beralamatkan di Jalan Panglima Sudirman No. 187 Kartoharjo Madiun adalah toko yang khusus menjual barang obral dan produk yang dijualpun hanya dari beberapa brand saja. Dan outlet yang ketiga yaitu Toko Stars Caruban yang beralamatkan di Jalan Panglima Sudirman No. 23 Caruban Kecamatan Mejayan Kabupaten Madiun.

Hasil wawancara dengan Bapak Moh. Arifin selaku supervisor/ kepala toko pada tanggal 13 April 2021 diketahui bahwa adanya pandemi covid 19 yang terjadi di Indonesia memberikan dampak signifikan terhadap sektor ekonomi. Toko Stars Madiun 2, yang bergerak dalam bidang jual beli ritel, juga terkena dampak pandemi tersebut. Yaitu turunnya omset penjualan secara drastis di semua cabang. Seiring berjalannya waktu, awal tahun 2021 secara perlahan penjualan di Toko Sepatu Stars cabang sudah mulai mengalami kenaikan, seperti di Toko Sepatu Stars cabang Caruban perlahan omset penjualan mulai naik. Namun, di Toko Sepatu Stars Madiun 2 masih belum mengalami kenaikan, padahal mulai dari harga yang diturunkan, melalui gebyar diskon. Untuk promosi, setiap hari karyawan toko mempromosikan produk di media sosial facebook dengan cara posting ataupun melakukan siaran langsung, kemudian dari segi pelayanan para karyawan sudah melayani konsumen dengan sangat ramah, dan apabila ada seorang customer yang menginginkan produk model A dengan ukuran semisal 42, jika stok di display maupun di Gudang habis pramuniaga selalu menawarkan model lain yang masih satu kategori dengan ukuran sesuai permintaan customer. Karena arahan dari pimpinan saat kembali dari Gudang, jika barang yang dicari kosong stoknya, tidak ada alasan untuk tidak membawa barang lain.

Berdasarkan hasil wawancara dengan Ibu Hasyim pada tanggal 17 April 2021 diketahui bahwa saat ini Toko Stars Madiun 2 memberikan diskon pada produk-produk yang dijual sehingga harga yang ada menjadi lebih murah dibandingkan dengan sebelumnya. Akan tetapi harga yang murah ini tidak membuat Ibu Hasyim untuk 
melakukan pembelian ulang karena kondisi pandemi yang mengakibatkan jarang keluar rumah sehingga belum membutuhkan produk yang ada di Toko Sepatu Stars Madiun 2. Begitu juga wawancara dengan Bapak Totok pada tanggal 21 April 2021, diketahui bahwa menurut Bapak Totok harga produk di Toko Stars Madiun 2 jauh lebih murah dibandingkan dengan toko lain, terutama pada sepatu merk Ardiles. Di Toko Stars Madiun 2, harga sepatu Ardiles harganya turun, sedangkan di toko lain harganya masih tinggi. Namun, hal ini tidak membuat Bapak Totok melakukan pembelian ulang dikarenakan Bapak Totok sedang banyak keperluan penting lain yang harus dibeli. Hasil wawancara ini menunjukkan bahwa adanya perbedaan teori dengan praktek yang mana secara teori ketika harga rendah maka konsumen akan cenderung melakukan pembelian ulang padahal kenyataannya tidak demikian dikarenakan ada alasan lain yang membuat Ibu Hasyim dan Bapak Totok tidak melakukan pembelian ulang. Selain itu didukung oleh perbedaan hasil penelitian yang dilakukan oleh Pravianti dan Hermani serta Cardia dkk dengan kesimpulan bahwa harga memberikan pengaruh signifikan pada loyalitas pelanggan(Cardia, Santika, \& Respati, 2019; Salim \& Hermani, 2018). Sedangkan penelitian yang dilakukan oleh Sola dan Rosnaida menunjukkan harga tidak berpengaruh terhadap loyalitas konsumen (Rosnaida, 2017; Sola, 2017). Berdasarkan hasil penelitian tersebut, masih terdapat ketidakkonsistenan pengaruh harga terhadap loyalitas konsumen, sehingga perlu dilakukan analisis lebih lanjut.

Kemudian, berdasarkan hasil wawancara dengan Ira pada tanggal 26 April 2021, diketahui bahwa Toko Sepatu Stars Madiun 2 sering melakukan promosi melalui sosial media facebook, promosi dilakukan dengan cara siaran langsung oleh pramuniaga yang mempromosikan produk baru maupun produk diskon, tidak hanya melalui siaran langsung, promosi juga dilakukan dengan cara memposting produk di beranda facebook. Di media sosial whatsApp pun pramuniaga juga sering memposting produk jualan di status whatsapp maupun melalui chatt personal kepada konsumen termasuk Ira. Akan tetapi walaupun Ira sering melihat iklan atau promosi ini, tidak membuat Ira melakukan pembelian ulang, dikarenakan Ira sedang memiliki kebutuhan lain yang harus dibeli. Hasil wawancara yang sama juga didapatkan dari wawancara dengan $\mathrm{Bu}$ Ismi pada tanggal 29 April 2021, yaitu Bu Ismi tidak melakukan pembelian ulang dikarenakan $\mathrm{Bu}$ Ismi yang berprofesi sebagai tenaga kesehatan sulit sekali meluangkan waktu untuk berbelanja keluar. Hal ini menunjukkan adanya perbedaan antara teori dan praktik yaitu, semakin sering dan menarik suatu promosi, maka cenderung akan 
mengundang konsumen untuk melakukan pembelian ulang. Selain itu didukung hasil penelitian yang berbeda yaitu penelitian yang dilakukan oleh Herawati dan Qomariyah serta Ghaisani dkk yang menunjukkan bahwa terdapat pengaruh positif antara promosi dengan loyalitas konsumen (Ghaisani, Darsiharjo, \& Miftah, 2016; Herawati \& Qomariyah, 2017). Sedangkan penelitian yang dilakukan oleh Noorhayati dan Aprilinda menunjukkan bahwa terdapat pengaruh negatif dan tidak signifikan anatar promosi dengan loyalitas konsumen (Aprilinda, 2019; Noorhayati, 2018). Dari hasil penelitian tersebut, masih terdapat ketidakkonsistenan pengaruh harga terhadap loyalitas konsumen, sehingga perlu dilakukan analisis lebih lanjut.

Berdasarkan hasil wawancara dengan Bu Tika dan Bu Fatma pada 1 Juni 2021, pelayanan yang dilakukan oleh Pramuniaga Toko Stars Madiun 2 sangatlah baik, ramah, dan juga sopan santun berbeda jauh dengan toko-toko lain, selain itu pelayan juga sangat sigap dan cepat, pramuniaga juga jujur terhadap kondisi dan kualitas produk yang ada, dan apabila ada pelanggan membawa anak kecil, saat anak kecil tersebut rewel pramuniaga juga ikut menghibur dan menenangkan. Juga pada masalah uang, saat transaksi pembayaran, apabila tidak ada kembalian yang pas, pramuniaga sering merelakan kekurangan pembayaran semisal ada kekurangan Rp. 1000 ataupun Rp. 2000. Di dalam Toko Sepatu Stars Madiun 2 kebersihan juga terjaga, tempat duduk untuk pelanggan yang ingin mencoba produk maupun sedang menunggu disediakan tempat duduk yang nyaman. Namun meskipun begitu, hal tersebut tidak membuat $\mathrm{Bu}$ Tika dan Bu Fatma melakukan pembelian ulang secara terus menerus di Toko Stars Madiun 2, dikarenakan kesibukan dan jarak rumah dengan toko yang lumayan jauh. Hal ini menunjukkan adanya ketidaksesuaian antara teori dan praktik, yaitu jika kualitas pelayanan baik dan memuaskan maka akan menciptakan loyalitas konsumen yang tinggi. Selain itu, juga didukung oleh perbedaan hasil penelitian yang dilakukan oleh beberapa peneliti. Seperti penelitian yang dilakukan oleh Aprilinda, Mursyid, dan Sola menunjukkan ada pengaruh signifikan antara kualitas pelayanan terhadap loyalitas konsumen(Aprilinda, 2019; Mursyid, 2018; Sola, 2017). Sedangkan penelitian yang dilakukan oleh Pradana menunjukkan bahwa tidak ada pengaruh yang signifikan antara kualitas pelayanan terhadap loyalitas konsumen(Izzah \& Chasanah, 2020; Pradana, 2018). Dengan adanya ketidaksesuaian antara teori dengan praktik dan juga perbedaan hasil penelitian yang dilakukan oleh beberapa peneliti, maka perlu dilakukan analisis ulang mengenai pengaruh kualitas pelayanan terhadap loyalitas konsumen. 
Berdasarkan hasil pemaparan di atas, terdapat ketidaksesuaian antara teori dengan praktik dan juga banyaknya perbedaan hasil penelitian pada variabel harga, promosi, dan kualitas pelayanan terhadap loyalitas konsumen, maka dilakukan penelitian dengan judul "Pengaruh Harga, Promosi, dan Kualitas Pelayanan Terhadap Loyalitas Konsumen Di Toko Stars Madiun 2".

\section{TINJAUAN LITERATUR}

\section{Loyalitas Konsumen}

Loyalitas pelanggan (customer loyalty) adalah komitmen konsumen pada suatu merek, toko ataupun pemasok, yang diwujudkan dalam sikap yang sangat positif dan perilaku pembelian berulang dan konsisten(Fandy Tjiptono, 2006). Loyalitas konsumen juga berarti komitmen jangka panjang dari konsumen, yang tercermin dengan perilaku dan sikap loyal terhadap perusahaan dan produknya. Sikap loyal tersebut dibuktikan melalui konsumsi yang teratur dan berkelanjutan, hingga perusahaan dan produknya menjadi bagian penting dari proses konsumsi tersebut(Priansa, 2017). Dapat disimpulkan bahwa loyalitas konsumen adalah sikap positif yang diberikan oleh konsumen kepada suatu produk atau perusahaan yang disebabkan oleh kepuasan konsumen terhadap produk atau perusahaan tersebut yang diwujudkan dengan perilaku pembelian berulang hingga merekomendasikannya kepada siapapun yang mereka kenal.

Loyalitas pelanggan atau konsumen sangat penting bagi perusahaan untuk menjaga kelangsungan usaha dan kegiatan usahanya. Pelanggan loyal adalah mereka yang sangat puas dengan produk dan layanan tertentu, sampai mereka bersemangat untuk memperkenalkannya kepada siapapun yang mereka kenal. Selain itu, pada fase selanjutnya, pelanggan yang loyal ini akan memperluas loyalitasnya ke produk lain dari produsen yang sama(Fandy Tjiptono, 2000).

\section{Harga}

Harga didefinisikan sebagai jumlah uang (satuan moneter) dan/atau aspek lain (non moneter) yang mencakup utilitas/penggunaan tertentu yang diperlukan untuk memperoleh barang atau jasa(Fandy Tjiptono, 2006). Menurut Sunarya, harga adalah sejumlah nilai (dalam mata uang) yang harus dikeluarkan konsumen untuk membeli atau menikmati barang atau jasa yang disediakan(Sunarya, Sudaryono, \& Saefullah, 2011). 
Menurut Kotler dan Armstrong, harga adalah biaya yang dikenakan untuk produk atau jasa. Dalam istilah yang lebih umum, harga adalah jumlah dari semua nilai pelanggan pada produk atau layanan. Harga selalu menjadi faktor utama yang mempengaruhi pilihan pembeli. Dalam beberapa dekade terakhir, faktor selain harga menjadi semakin penting. Akan tetapi, harga tetap menjadi faktor terpenting dalam menentukan pangsa pasar dan keuntungan perusahaan(Philips Kotler \& Armstrong, 2008).

Harga adalah satu-satunya elemen dalam bauran pemasaran yang menghasilkan pendapatan, dan juga yang paling fleksibel(Philip Kotler \& Keller, 2009). Perusahaan harus mempertimbangkan banyak faktor ketika membuat keputusan penetapan harga. Pertama, perusahaan harus memutuskan di mana akan memasarkan produknya. Semakin jelas tujuan perusahaan, semakin mudah juga penetapan harga oleh perusahaan(Philip Kotler \& Keller, 2009). Dari beberapa pengertian di atas, dapat disimpulkan bahwa, harga adalah nilai atau nominal dari suatu produk yang harus dibayarkan oleh konsumen kepada penjual yang dijadikan sebagai syarat kepemilikan atas produk tersebut.

\section{Promosi}

Dalam bahasa Inggris, promosi disebut dengan promotion, yang berarti kemajuan. Dari segi produk, promosi adalah upaya mengiklankan atau memajang produk agar produk lebih cepat terjual dan usaha produksi lebih maju(Sarmadi, 2012). Segala bentuk promosi merupakan upaya untuk mempengaruhi pihak lain. Lebih khusus lagi, promosi merupakan salah satu elemen dari bauran pemasaran perusahaan(Setiyaningrum, 2015). Promosi juga bisa disebut sebagai kegiatan yang dilakukan untuk meningkatkan penjualan. Biasanya, dalam promosi semacam ini, pemilik produk berusaha memuji dan mengungkapkan keunggulan produk yang dijualnya(Alma \& Priansa, 2009). Promosi adalah kegiatan marketing mix terakhir setelah produk, harga dan lokasi, dan inilah yang paling sering didefinisikan sebagai kegiatan pemasaran dalam arti sempit. Aktivitas tersebut meliputi aktivitas penting selain produk, harga, dan lokasi(Al Arif, 2010). Dapat disimpulkan bahwa promosi adalah suatu kegiatan yang dilakukan oleh perusahaan untuk mengenalkan produknya kepada masyarakat yang bertujuan menarik masyarakat agar membeli produk tersebut. 
Perusahaan harus ikut serta berperan aktif dalam kegiatan promosi, karena promosi merupakan sarana informasi yang diberikan perusahaan kepada konsumen tentang produk yang ditawarkan dan keuntungan apa yang akan diperoleh pelanggan dari membeli atau mengonsumsi produk tersebut(Anggraini \& Budiarti, 2020). Tanpa promosi, konsumen tidak akan dapat mengidentifikasi produk atau jasa yang ditawarkan. Oleh karena itu, promosi merupakan cara yang paling ampuh untuk menarik dan mempertahankan konsumen(Kasmir, 2016).

\section{Kualitas Pelayanan}

Kualitas diartikan sebagai tingkat mutu yang diinginkan, dan pengendalian keragaman mencapai mutu tersebut adalah untuk memenuhi kebutuhan konsumen(Laksana, 2008). Menurut Moenir pelayanan merupakan suatu proses pemenuhan kebutuhan melalui tindakan orang lain secara langsung(Moenir, 2010). Kualitas pelayanan merupakan tingkat aktivitas pelayanan yang diberikan perusahaan atau karyawan kepada konsumen. Kualitas pelayanan itu sendiri dapat menjadi acuan bagi konsumen untuk mengambil keputusan ketika membeli produk. Kualitas pelayanan dapat diukur melalui lima dimensi sesuai urutan kepentingan relatifnya, yaitu keandalan, jaminan, bukti fisik, empati dan daya tanggap(Rizqia, 2018).

Pelayanan yang berkualitas tinggi memegang peranan yang sangat penting dalam membentuk kepuasan pelanggan dan juga berkaitan dengan hasil keuntungan bagi perusahaan. Kualitas pelayanan yang tinggi dapat meningkatkan kepuasan pelanggannya yang pada akhirnya dapat meningkatkan loyalitas pelanggan tersebut.

\section{METODE PENELITIAN}

Penelitian ini adalah jenis penelitian asosiatif untuk mengetahui pengaruh satu variabel ke variabel lainnya. Variabel bebas adalah harga, promosi, dan kualitas pelayanan sedangkan variabel terikatnya adalah loyalitas konsumen. Populasi pada penelitian ini adalah konsumen Toko Stars Madiun 2 dengan jumlah sampel 97 konsumen. Metode incidental sampling dipilih sebagai metode pengambilan sampel. Data dikumpulkan dengan penyebaran kuesioner. Kuesioner disusun dengan mempertimbangkan kisi-kisi pada Tabel 1. 
Tabel 1. Indikator Masing-masing Variabel

\begin{tabular}{|c|c|c|}
\hline Variabel & Indikator & Butir Soal \\
\hline \multirow{4}{*}{$\begin{array}{c}\text { Harga } \\
\left(\mathrm{X}_{1}\right)\end{array}$} & Keterjangkauan harga & 1,2 \\
\hline & Harga sesuai kemampuan atau daya saing harga. & 3,4 \\
\hline & Kesesuaian harga dengan kualitas produk & 5,6 \\
\hline & Kesesuaian harga dengan manfaat & 7,8 \\
\hline \multirow{4}{*}{$\begin{array}{l}\text { Promosi } \\
\qquad\left(\mathrm{X}_{2}\right)\end{array}$} & Periklanan (advertising) & 9,10 \\
\hline & Personal Selling & 11,12 \\
\hline & Publisitas & 13,14 \\
\hline & Promosi Penjualan & 15,16 \\
\hline \multirow{5}{*}{$\begin{array}{c}\text { Kualitas } \\
\text { Pelayanan } \\
\left(\mathrm{X}_{3}\right)\end{array}$} & Tampilan fisik (tangible) & 17,18 \\
\hline & Kehandalan (reliability) & 19,20 \\
\hline & Daya Tanggap (responsiveness) & 21,22 \\
\hline & Jaminan (assurance) & 23,24 \\
\hline & Kepedulian (emphaty) & 25,26 \\
\hline \multirow{6}{*}{$\begin{array}{c}\text { Loyalitas } \\
\text { Pelanggan } \\
\text { (Y) }\end{array}$} & Kepuasan menggunakan produk & 27,28 \\
\hline & Berkomitmen menggunakan produk. & 29,30 \\
\hline & Tidak membeli produk pesaing. & 32,32 \\
\hline & Merekomendasikan produk kepada orang lain. & 33,34 \\
\hline & Tidak mencoba produk lain. & 35,36 \\
\hline & Melakukan pembelian produk secara berulang. & 37,38 \\
\hline
\end{tabular}

Skala pengukuran kuesioner dilakukan dengan skala likert dengan 4 respon jawaban yaitu SS, S, TS, dan STS. Data yang diperoleh selanjutnya dianalisis menggunakan metode Partial Least Square (PLS) dengan tahapan evaluasi outer model dan evaluasi inner model.

\section{HASIL DAN PEMBAHASAN}

\section{Pengujian Validitas dan Reliabilitas}

Pengujian validitas dan reliabilitas dipakai untuk memastikan bahwa instrumen yang disusun memenuhi kriteria validitas dan reliabilitas. pengujian ini dilakukan secara terbatas kepada 30 orang responden. Hasil pengujian validitas menunjukkan bahwa semua item pernyataan dari variabel $\mathrm{X}_{1}, \mathrm{X}_{2}, \mathrm{X}_{3}$, dan $\mathrm{Y}$ memenuhi kriteria validitas karena nilai $\mathrm{r}_{\text {hitung }}$ yang diperoleh lebih dari 0,361. Untuk hasil pengujian reliabilitas diperoleh nilai cronbach alpha lebih dari 0,7 sehingga variabel $\mathrm{X}_{1}, \mathrm{X}_{2}, \mathrm{X}_{3}$, dan $\mathrm{Y}$ reliabel. Karena kuesioner yang disusun telah valid dan reliabel, selanjutnya kuesioner ini dipakai untuk mengumpulkan data dari responden. 


\section{Deskriptif Data Responden}

Kuesioner disebarkan kepada 97 responden yang merupakan konsumen Toko Stars Madiun 2 dapat diperoleh gambaran dari responden ditunjukkan pada Gambar 1-3.

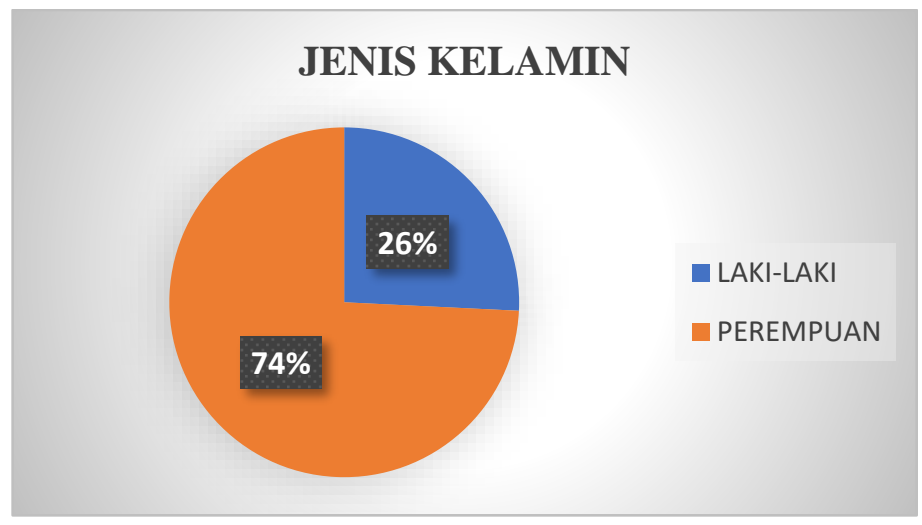

\section{Gambar 1. Responden Berdasarkan Jenis Kelamin}

Gambar 1 adalah pie chart dari jenis kelamin responden pada penelitian ini. Dari 97 responden yang terlibat dalam penelitian, sebanyak 72 responden atau $74 \%$ adalah berjenis kelamin perempuan sedangkan 25 responden atau $26 \%$ adalah berjenis kelamin laki-laki yang menunjukkan bahwa responden pada penelitian Sebagian besar adalah perempuan.

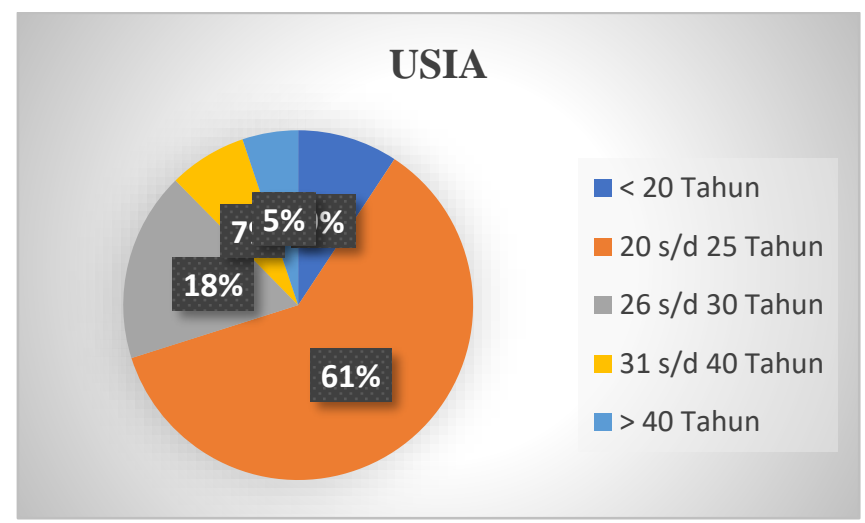

Gambar 2. Responden Berdasarkan Usia

Gambar 2 adalah pie chart responden didasarkan pada usia. Hasil tersebut menunjukkan bahwa dari 97 responden, sebanyak 9\% responden berusia $<20$ tahun, $61.7 \%$ responden berusia $20 \mathrm{~s} / \mathrm{d} 25$ tahun, $18 \%$ responden berusia $26 \mathrm{~s} / \mathrm{d} 30$ tahun, $7 \%$ responden berusia $31 \mathrm{~s} / \mathrm{d} 40$ tahun, dan $5 \%$ responden berusia $>40$ tahun. Hasil ini memperlihatkan bahwa usia responden paling banyak $20 \mathrm{~s} / \mathrm{d} 25$ tahun. 


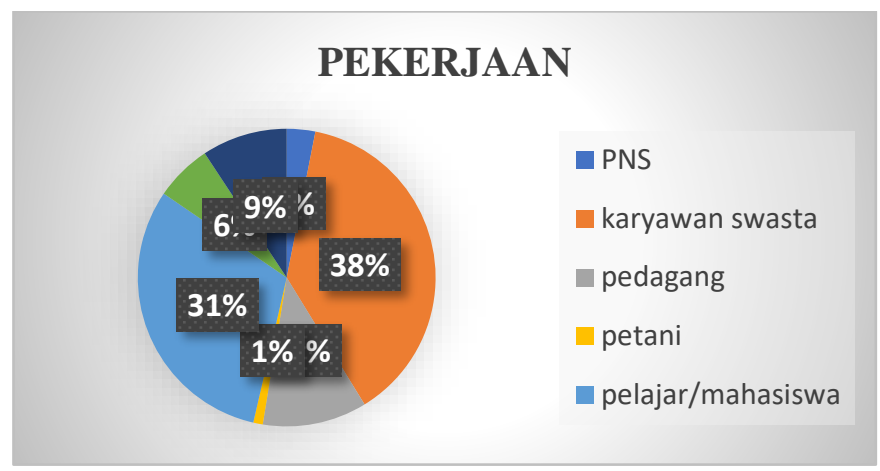

Gambar 3. Responden Berdasarkan Pekerjaan

Berdasarkan Gambar 3, dapat diketahui bahwa proporsi dari 97 responden berdasarkan dari pekerjaan adalah, sebanyak 3\% bekerja sebagai PNS, 38\% bekerja sebagai karyawan swasta, $12 \%$ bekerja sebagai pedagang, $1 \%$ bekerja sebagai petani, $31 \%$ sebagai pelajar/ mahasiswa, $6 \%$ sebagai ibu rumah tangga, dan $9 \%$ bekerja pada bidang lainnya.

\section{Evaluasi Outer Model}

\section{Validitas Konvergen}

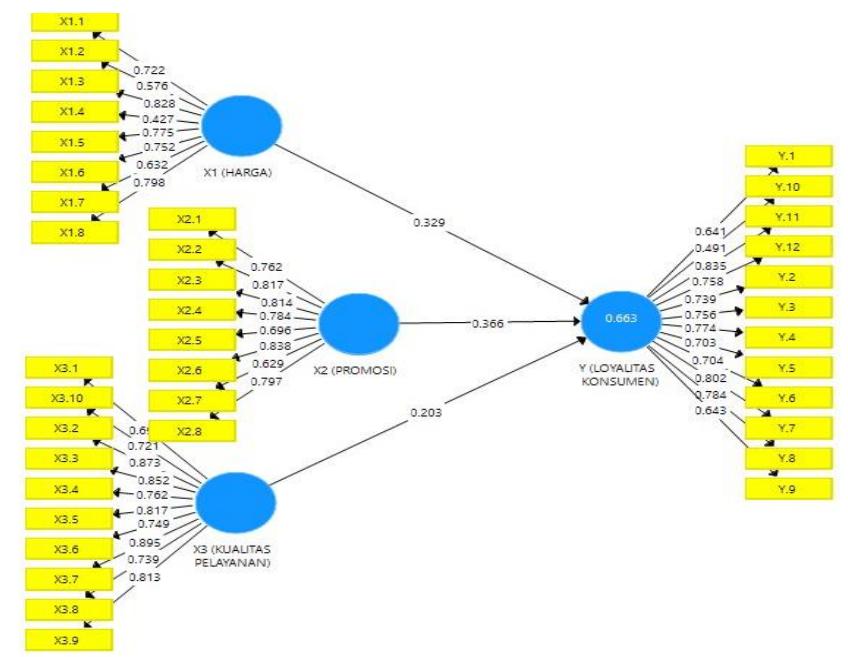

Gambar 4 Loading Factor Model Pertama

Gambar 4 menunjukkan bahwa model pertama memiliki tiga item pernyataan dengan nilai loading factor di bawah 0,6. Item pernyataan tersebut adalah $\mathrm{X}_{1.2}, \mathrm{X}_{1.4}$ dan $\mathrm{Y}_{10}$. Ketiga item pernyataan dikeluarkan dari model. Model yang baru selanjutnya dieksekusi dan diperoleh loading factor pada Tabel 2. Hasil estimasi outer model koreksi pada Tabel 2 menunjukkan bahwa semua item pada 
setiap variabel memiliki loading factor diatas 0,6 sehingga variabel harga, promosi, kualitas pelayanan, dan loyalitas konsumen memenuhi validitas konvergen.

Tabel 2. Nilai Loading Factor Model Koreksi

\begin{tabular}{|c|c|c|c|c|}
\hline & $\mathrm{X}_{1}$ & $X_{2}$ & $\mathrm{X}_{3}$ & $\mathrm{Y}$ \\
\hline $\mathrm{X}_{1.1}$ & 0,73 & & & \\
\hline $\mathrm{X}_{1.3}$ & 0,84 & & & \\
\hline $\mathrm{X}_{1.5}$ & 0,783 & & & \\
\hline $\mathrm{X}_{1.6}$ & 0,777 & & & \\
\hline $\mathrm{X}_{1.7}$ & 0,631 & & & \\
\hline $\mathrm{X}_{1.8}$ & 0,81 & & & \\
\hline $\mathrm{X}_{2.1}$ & & 0,763 & & \\
\hline$X_{2.2}$ & & 0,817 & & \\
\hline $\mathrm{X}_{2.3}$ & & 0,815 & & \\
\hline $\mathrm{X}_{2.4}$ & & 0,786 & & \\
\hline $\mathrm{X}_{2.5}$ & & 0,694 & & \\
\hline$X_{2.6}$ & & 0,837 & & \\
\hline $\mathrm{X}_{2.7}$ & & 0,63 & & \\
\hline $\mathrm{X}_{2.8}$ & & 0,797 & & \\
\hline$X_{3.1}$ & & & 0,692 & \\
\hline$X_{3.10}$ & & & 0,722 & \\
\hline$X_{3.2}$ & & & 0,873 & \\
\hline $\mathrm{X}_{3.3}$ & & & 0,852 & \\
\hline$X_{3.4}$ & & & 0,763 & \\
\hline $\mathrm{X}_{3.5}$ & & & 0,817 & \\
\hline $\mathrm{X}_{3.6}$ & & & 0,749 & \\
\hline $\mathrm{X}_{3.7}$ & & & 0,895 & \\
\hline $\mathrm{X}_{3.8}$ & & & 0,739 & \\
\hline $\mathrm{X}_{3.9}$ & & & 0,813 & \\
\hline$Y_{.1}$ & & & & 0,645 \\
\hline Y.11 & & & & 0,836 \\
\hline$Y_{.12}$ & & & & 0,762 \\
\hline$Y_{.2}$ & & & & 0,754 \\
\hline$Y_{.3}$ & & & & 0,775 \\
\hline$Y_{.4}$ & & & & 0,77 \\
\hline $\mathrm{Y} .5$ & & & & 0,715 \\
\hline$Y_{.6}$ & & & & 0,7 \\
\hline$Y_{.7}$ & & & & 0,796 \\
\hline$Y_{.8}$ & & & & 0,767 \\
\hline$Y_{.9}$ & & & & 0,646 \\
\hline
\end{tabular}

Sumber: Data diolah (2021)

\section{Validitas Diskriminan}

Tabel 3 memperlihatkan bahwa nilai akar AVE varibel $\mathrm{X}_{1}$ adalah 0,765; variabel $\mathrm{X}_{2}$ adalah 0,770 ; variabel $\mathrm{X}_{3}$ adalah 0,794 dan variabel $\mathrm{Y}$ adalah 0,744. 
Nilai akar AVE ini lebih besar dari pada nilai korelasi antar variabel. Hal ini mengindikasikan bahwa model valid karena memenuhi validitas diskriminan.

Tabel 3. Hasil Evaluasi Validitas Diskriminan

\begin{tabular}{ccccc}
\hline & $X_{1}$ & $X_{2}$ & $X_{3}$ & $Y$ \\
\hline$X_{1}$ & $\mathbf{0 , 7 6 5}$ & & & \\
\hline$X_{2}$ & 0,719 & $\mathbf{0 , 7 7 0}$ & & \\
\hline$X_{3}$ & 0,695 & 0,730 & $\mathbf{0 , 7 9 4}$ & \\
\hline$Y$ & 0,746 & 0,747 & 0,702 & $\mathbf{0 , 7 4 4}$
\end{tabular}

Sumber: Data diolah (2021)

\section{Uji Reliabilitas Komposit}

Tabel 4. Hasil Uji Reliabilitas Komposit

\begin{tabular}{cc}
\hline & Reliabilitas Komposit \\
\hline $\mathrm{X}_{1}$ & 0,894 \\
\hline $\mathrm{X}_{2}$ & 0,920 \\
\hline $\mathrm{X}_{3}$ & 0,944 \\
\hline $\mathrm{Y}$ & 0,931
\end{tabular}

Sumber: Data diolah (2021)

Uji reliabilitas komposit digunakan pada penelitian ini karena lebih konsisten. Tabel 4 memperlihatkan nilai reliabilitas komposit dari variabel harga adalah 0,894; variabel promosi adalah 0,920 ; variabel kualitas pelaayanan adalah 0,944 dan variabel harga adalah 0,931. Nilai reliabilitas komposit masing-masing variabel lebih dari 0,7 yang mengindikasikan model telah memenuhi pengujian reliabilitas.

\section{Evaluasi Inner Model}

\section{Model Persamaan Struktural}

Tabel 5. Koefisien Inner Model

\begin{tabular}{lccc}
\hline & Original Sample & T Statistics & $P$ Values \\
\hline $\mathrm{X}_{1} \rightarrow \mathrm{Y}$ & 0,361 & 3,034 & 0,003 \\
\hline $\mathrm{X}_{2} \rightarrow \mathrm{Y}$ & 0,340 & 2,689 & 0,007 \\
\hline $\mathrm{X}_{3} \rightarrow \mathrm{Y}$ & 0,203 & 1,604 & 0,109 \\
\hline
\end{tabular}

Sumber: Data diolah (2021) 
Model persamaan struktural yang dibentuk dari hasil yang koefisien inner model pada Tabel 5 sebagai berikut:

$$
\eta_{\text {loyalitas }}=0,361 \xi_{1}+0,340 \xi_{2}+0,203 \xi_{3}+2
$$

dimana

$\eta_{\text {loyalitas }} \quad$ : Loyalitas

$\xi_{1} \quad$ : Harga

$\xi_{2} \quad:$ Promosi

$\xi_{3} \quad:$ Kualitas pelayanan

२ : Error model structural

Dari model persamaan struktural yang terbentuk dan pengujian parameter model dapat dijelaskan sebagai berikut

a. Variabel harga memiliki nilai $t$ statistic sebesar 3,034 dan p-value 0,003 kurang dari 0,05 sehingga variabel harga memiliki pengaruh positif dan signifikan pada loyalitas konsumen Toko Star Madiun 2. Koefisien variabel harga sebesar 0,361 mengindikasikan bahwa semakin sesuai harga yang ditawarkan oleh Toko Star Madiun 2 maka loyalitas konsumen akan semakin meningkat.

b. Variabel promosi memiliki nilai $t$ statistic sebesar 2,689 dan p-value 0,007 kurang dari 0,05 sehingga variabel promosi memiliki pengaruh positif dan signifikan pada loyalitas konsumen Toko Star Madiun 2. Koefisien variabel promosi sebesar 0,340 mengindikasikan bahwa semakin sering promosi dilakukan oleh Toko Star Madiun 2 maka loyalitas konsumen akan semakin meningkan. Lebih jauh, jika promosi yang dilakukan oleh Toko Star Madiun 2 meningkat 1 satuan maka loyalitas akan meningkat sebesar 0,340 satuan.

c. Variabel kualitas pelayanan memiliki nilai $t$ statistic sebesar 1,604 dan p-value 0,109 lebih dari 0,05 sehingga variabel kepuasan pelayanan memiliki pengaruh positif tetapi tidak signifikan pada loyalitas konsumen Toko Star Madiun 2.

\section{Koefisien Determinasi}

Tabel 6. Variabel Paling Dominan

\begin{tabular}{ccccc}
\hline Variabel & Koefisien & $\mathrm{r}_{\text {hitung }}$ & Kontribusi & $\mathrm{R}^{2}$ \\
\cline { 1 - 4 } $\mathrm{X}_{1}$ & 0,361 & 0,746 & 26,9 & $66,5 \%$ \\
\cline { 1 - 4 } $\mathrm{X}_{2}$ & 0,340 & 0,747 & 25,3 & \\
\cline { 1 - 4 } $\mathrm{X}_{3}$ & 0,203 & 0,702 & 14,2 & \\
\hline
\end{tabular}

Sumber: Data diolah (2021) 
Nilai $R^{2}$ dari model struktural yang diperoleh adalah 0,665 mengindikasikan bahwa semua variabel independen mampu menjelaskan variabilitas dari variabel loyalitas konsumen sebesar $66,5 \%$ dan sisanya 33,5 dipengaruhi faktor lain diluar model. Hasil perhitungan pada Tabel 6 menunjukkan bahwa variabel yang paling dominan memberikan pengaruh pada loyalitas konsumen adalah variabel harga dengan besaran kontribusi $26,9 \%$ disusul variabel promosi dengan kontribusi $25,3 \%$ dan terakhir adalah variabel kualitas pelayanan dengan konttribusi $14, \%$.

\section{Pengaruh harga terhadap loyalitas konsumen}

Harga memberikan pengaruh positif dan signifikan pada loyalitas konsumen karena nilai $t$ statistic 3,034 dan p-value $0,003<0,05$. Koefisien variabel harga sebesar 0,361 mengindikasikan bahwa semakin sesuai harga yang ditawarkan oleh Toko Star Madiun 2 maka loyalitas konsumen akan semakin meningkat. Hasil ini bersesuaikan dengan penelitian yang dilakukan oleh Cardia dkk, Rosnaida serta Pravianti dan Hermani yang menunjukkan bahwaa harga berpengaruh positif dan signifikan pada loyalitas konsumen(Cardia dkk., 2019; Salim \& Hermani, 2018). Berdasarkan hasil ini, Toko Stars Madiun 2 diharapkan dapat memberikan harga yang lebih kompetitif dan bermacam-macam disesuaikan dengan kualitas produk yang dijual tujuannya agar loyalitas konsumen yang ada saat ini semakin meningkat dan tidak memilih toko lainnya.

\section{Pengaruh Promosi Terhadap Loyalitas Konsumen}

Promosi memberikan pengaruh positif dan signifikan pada loyalitas konsumen Toko Star Madiun 2 karena nilai $t$ statistic sebesar 2,689 dan p-value 0,007<0,05. Koefisien variabel promosi sebesar 0,340 mengindikasikan bahwa semakin sering promosi dilakukan oleh Toko Star Madiun 2 maka loyalitas konsumen akan semakin meningkan. Lebih jauh, jika promosi yang dilakukan oleh Toko Star Madiun 2 meningkat 1 satuan maka loyalitas akan meningkat sebesar 0,340 satuan. Hasil ini bersesuaian dengan penelitian Herawati dan Qomariyah serta Ghaisani dkk yang menunjukkan bahwa promosi memberikan pengaruh positif pada loyalitas konsumen(Ghaisani dkk., 2016; Herawati \& Qomariyah, 2017). Berdasarkan hasil tersebut, Toko Stars Madiun 2 diharapkan dapat melakukan promosi yang semakin 
menarik, semakin intens, dan semakin luas, seperti halnya promosi yang sudah dilakukan di sosial media facebook, diharapkan dapat diperluas melalui media sosial Instagram dan twitter. Selain itu, Toko Stars Madiun 2 juga diharapakan dapat memperluas promosi dalam bentuk lain, seperti pemberian diskon harga, hadiah-hadiah menarik dalam minimal pembelian, promo mingguan ataupun promo bulanan.

\section{Pengaruh Kualitas Pelayanan Terhadap Loyalitas Konsumen}

Kualitas pelayanan tidak berpengaruh pada loyalitas konsumen karena nilai $t$ statistic sebesar 1,604 dan p-value 0,109>0,05. Hasil ini sesuai dengan penelitian Pradana dan Izzah dan Chasanah yang menunjukkan bahwa tidak ada pengaruh yang signifikan antara kualitas pelayanan terhadap loyalitas konsumen(Izzah \& Chasanah, 2020; Pradana, 2018). Hasil ini mengindikasikan bahwa Toko Star Madiun 2 harus sungguh-sungguh memperbaiki kualitas pelayanan yang diberikan agar mampu memberikan kontribusi pada peningkatan loyalitas konsumen.

\section{KESIMPULAN}

Berdasarkan hasil analisis data dan pembahasan dapat disimpulkan bahwa harga dan promosi memberikan pengaruh positif dan signifikan pada loyalitas konsumen Toko Star Madiun 2 tetapi kualitas pelayanan tidak memberikan pengaruh pada loyalitas konsumen. Harga adalah variabel yang paling dominan memberikan pengaruh pada loyalitas konsumen Toko stars Madiun 2 dengan konstribusi sebesar 26,9\%, disusul variabel promosi sebesar 25,3\% dan varaibel kualitas pelayanan sebesar 14,2\% . Toko Star Madiun 2 dapat meningkatkan loyalitas konsumen dengan jalan memberikan harga yang baik, dalam artian lebih kompetitif, variatif, dan diiringi dengan kualitas yang semakin baik. Selain itu, dapat memperluas promosi dengan memberikan promo mingguan ataupun bulanan, memberikan hadiah menarik, memberikan cashback pada transaksi dengan minimal pembelian tertentu, juga mengikuti event-event bazar ataupun sunday market yang diadakan Kota Madiun setiap akhir pekan.

Dari hasil penelitian menunjukkan variabel harga, promosi, dan kualitas pelayanan berpengaruh sebesar $66,5 \%$ dengan $35,5 \%$ dipengaruhi faktor lain diluar model. Berdasarkan hasil tersebut, penelitian yang akan datang dapat dilakukan dengan memilih variabel lain yang mempengaruhi loyalitas konsumen seperti, lokasi, kepuasan 
konsumen, citra merek, serta kepercayaan aar diperoleh model yang lebih sesuai dengan nilai $\mathrm{R}^{2}$ yang tinggi.

\section{REFERENSI}

Al Arif, M. N. R. (2010). Dasar-Dasar Pemasaran Bank Syariah. Bandung: ALFABETA.

Alma, B., \& Priansa, D. J. (2009). Manajemen Bisnis Syariah. Bandung: ALFABETA. Anggraini, F., \& Budiarti, A. (2020). Pengaruh Harga, Promosi, dan Kualitas Pelayanan Terhadap Loyalitas Pelanggan Dimediasi Kepuasan Pelanggan Pada Konsumen Gojek. Jurnal Pendidikan Ekonomi (JUPE), 8(3), 86-94. https://doi.org/10.26740/jupe.v8n3.p86-94

Aprilinda, P. (2019). Pengaruh Kualitas Pelayanan Kualitas Produk dan Promosi Terhadap Loyalitas Pelanggan Pada Kedai Kings Coffee Lippo Cikarang (Skripsi). Universitas Pelita Bangsa, Bekasi.

Arnina P. (2016). Langkah-Langkah Efektif Menyusun SOP. Depok: Huta Publisher.

Atmaja, J. (2018). Kualitas Pelayanan dan Kepuasan Nasabah Terhadap Loyalitas Pada Bank BJB. Jurnal ECODEMICA, 2(1), 49-63.

Cardia, D. I. N. R., Santika, I. W., \& Respati, N. N. R. (2019). PENGARUH KUALITAS PRODUK, HARGA, DAN PROMOSI TERHADAP LOYALITAS PELANGGAN. E-Jurnal Manajemen, 8(11), 6762-6781. https://doi.org/10.24843/EJMUNUD.2019.v08.i11.p19

Dharmmesta, B. S. (1999). Loyalitas pelanggan: Sebuah kajian konseptual sebagai panduan bagi peneliti. Jurnal ekonomi dan bisnis Indonesia, 14(3).

Ghaisani, R. P., Darsiharjo, \& Miftah, R. (2016). PENGARUH PROMOSI TERHADAP LOYALITAS KONSUMEN DI SUIS BUTCHR STAK HOUSE SETIABUDHI BANDUNG. The Journal Gastronomy Tourism, 3(1), 255-264.

Hasan, A. (2015). Tourism Marketing. Yogyakarta: CAPS.

Herawati, N., \& Qomariyah, N. (2017). PENGARUH BAURAN PEMASARAN TERHADAP LOYALITAS PELANGGAN DENGAN KEPUASAN PELANGGAN SEBAGAI VARIABEL INTERVENING (STUDI EMPIRIS PELANGGAN SEPEDA MOTOR MATIC HONDA DI SURAKARTA). BHIRAWA, 4(1), 1-15.

Huda, N., Novarini, Mardoni, Y., \& Sari, C. P. (2015). Zakat: Perspektif mikro-makro pendekatan riset. Jakarta: Kencana Prenada Media.

Hurriyati, R. (2015). Bauran Pemasaran dan Loyalitas Konsumen. Bandung: Alfabeta.

Insani, N. A., \& Madiawati, P. N. (2020). Pengaruh Citra Merk dan Lokasi Terhadap Loyalitas Konsumen. Jurnal Ilmiah MEA, 4, 21.

Izzah, D., \& Chasanah, U. (2020). Pengaruh Kualitas Pelayanan, Citra Merek, dan Harga terhadap Loyalitas dengan Kepuasan Konsumen sebagai Pemediasi pada Sinau Kopi PT. Abadi Bina Indonesia. (Skripsi). STIE Widya Wiwaha, Yogyakarta.

Kasmir. (2016). Kewirausahaan. Jakarta: Rajawali Press.

Khaihatu, T. S., Daengs, A., \& Indrianto, A. L. (2015). Manajemen Komplain. Yogyakarta: Andi Offset.

Kotler, Philip, \& Keller, L. K. (2009). Manajemen Pemasaran Edisi 13 Jilid 2. Jakarta: Erlangga. 
Kotler, Philips, \& Armstrong, G. (2008). Prinsip-prinsip Pemasaran edisi 12. Jakarta: Erlangga.

Laksana, F. (2008). Manajemen Pemasaran Pendekatan Praktis. Yogyakarta: Graha Ilmu.

Lupiyoadi, R. (2008). Manajemen Pemasaran Jasa. Jakarta: Salemba Empat.

Moenir. (2010). Manajemen Pelayanan Umum di Indonesia. Jakarta: Bumi Aksara.

Mursyid, G. M. (2018). Pengaruh Promosi, Kualitas Pelayanan dan Harga Terhadap Loyalitas Konsumen (Studi Empiris Pada Pelanggan Foto Studio 26 Surakarta. (Skripsi). Universitas Muhammadiyah Surakarta, Surakarta.

Noorhayati, N. (2018). PENGARUH KUALITAS PRODUK, HARGA, DAN PROMOSI TERHADAP LOYALITAS PELANGGAN KARTU PRABAYAR TELKOMSEL (Studi Kasus Pada Mahasiswa STIE Muara Teweh). Jurnal Ekonomi Dan Manajemen, 12(1), 42-52.

Pradana, F. (2018). Pengaruh Manajemen Hubungan Pelanggan, Kualitas Pelayanan, Dan Kualitas Pengalaman Terhadap Loyalitas Pelanggan Dengan Kepuasan Pelanggan Sebagai Variabel Intervening Pada Nasabah Pt Fac Sekuritas Indonesia Di Yogyakarta. Jurnal Manajemen Bisnis, 9(2), 193-212. https://doi.org/10.18196/mb.9262

Priansa, D. J. (2017). Perilaku Konsumen Dalam Persaingan Bisnis Kontemporer. Bandung: Alfabeta.

Rizqia, F. (2018). Pengaruh Labelisasi Halal, Harga dan Kualitas Pelayanan, Terhadap Keputusan Pembelian Halal Food, di Studio Foodcourt Tunjungan Plaza Surabaya (Skripsi). Universitas Islam Negeri sunan Ampel Surabaya, Surabaya.

Rosnaida, R. (2017). PENGARUH CITRA MEREK, HARGA DAN KUALITAS PRODUK TERHADAP LOYALITAS KONSUMEN KECAP INDOFOOD (STUDI KASUS PADA IBU - IBU RUMAH TANGGA DESA BUNUT SEBERANG KEC. PULO BANDRING). JURNAL PIONIR, 2(3), 1-13.

Salim, A. P., \& Hermani, A. (2018). PENGARUH HARGA DAN KUALITAS PRODUK TERHADAP LOYALITAS PELANGGAN (Studi Pada Pelanggan Pasta Gigi Formula berusia > 15 tahun di Kelurahan Bulusan dan Tembalang, Kecamatan Tembalang, Semarang). Jurnal Ilmu Administrasi Bisnis, 7(2), 107115.

Sarmadi, S. (2012). Spiritualitas Bisnis Mencari Ridho Ilahi. Yogyakarta: CV. Aswaja Pressindo.

Setiyaningrum, A. (2015). Prinsip-Prinsip Pemasaran. Yogyakarta: Andi Offset.

Sola, K. I. (2017). Pengaruh harga, kualitas produk dan kualitas pelayanan terhadap loyalitas pelanggan (studi kasus pada Sakola Factory Outlet Jogja) (Skripsi, Sanata Dharma University). Sanata Dharma University, Yogyakarta. Diambil dari https://repository.usd.ac.id/22915/

Suarmawan, K. A. (2015). ANALISIS FAKTOR-FAKTOR YANG MEMPENGARUHI KEBERHASILAN USAHA MIKRO DAN KECIL (STUDI PADA USAHA KERAJINAN INGKA DI DESA BULIAN, KEC. KUBUTAMBAHAN). Jurnal Pendidikan Ekonomi Undiksha, 5(1), 1-10. https://doi.org/10.23887/jjpe.v5i1.6377

Sukpa, W. D., Wijayanto, G., \& Taufiqurrahman. (2015). Pengaruh kualitas pelayanan, kebijakan harga terhadap kepuasan dan loyalitas pelanggan pada jasa lapangan Internasional futsal Pekanbaru. Jom FEKON, 2(1), 1-18. 
Niqosiya: Journal of Economics and Business Research

Vol. 1 No. 2, Juli-Desember 2021: 197-216

Sunarya, A., Sudaryono, \& Saefullah, A. (2011). Kewirausahaan. Yogyakarta: Andi Offset.

Tjiptono, Fandy. (2014). Pemasaran Jasa. Yogyakarta: Andi Offset.

Tjiptono, Fandy. (2000). Prinsip \& Dinamika Pemasaran (Pertama). Yogyakarta: J \& Learning.

Tjiptono, Fandy. (2006). Pemasaran Jasa. Malang: Bayu Media. 